\title{
CONSUMER PROTECTION IN PRACTICE - A TRANSNATIONAL COMPARATIVE ACCOUNT OF COLLECTIVE REDRESS MECHANISMS
}

\author{
(Part two: the Dutch and the English approaches) ${ }^{2}$
}

This article constitutes a continuation of the research conducted so far in the domain of collective consumer redress in the European Union. The aim of the article is to discuss the issue of various legal mechanisms functioning in the selected EU Member States that serve consumers as a means of collective redress. In the first part of this paper, it was presented that the models of consumer protection vary significantly in the individual Member States. After having scrutinized some terminological remarks regarding consumer law enforcement, the main analysis focuses on the legal solutions adopted in Belgium. In the second part of the discussion, the author presents relevant legal solutions adopted in the UK and the Netherlands. Specifically, the author discusses the various approaches to the issues fitting in the dichotomic scheme, that is, the so-called opt-out and opt-in mechanisms. Special consideration is devoted to the issue of admissibility of collective redress and legal standing to bring collective actions. The paper employs dogmatic and analytical methods for the process of interpretation of the normative material and the analysis of case law. The study uses the comparative perspective to identify solutions emerging from effective practices found in legal systems of the EU Member States. The findings emerging from the analysis show how significantly the Dutch and English systems of collective redress vary. The article also provides some tentative conclusions that would make it possible to decide which legal solutions operating with success in those jurisdictions could be adopted into Polish law.

Keywords: Consumer disputes, collective redress, private enforcement, class action, group settlement, group litigation order.

\footnotetext{
${ }^{1}$ Jagna Mucha, PhD, University of Warsaw, Poland, recipient of the scholarship granted by the Foundation for Polish Science (FNP); e-mail: jagna.mucha@uw.edu.pl. ORCID: 0000-0003-48831252.

2 The paper constitutes a part of the research project "Consumer collective redress in the Polish group proceedings in light of European law standards - challenges and achievements", funded by the Polish National Science Centre within the framework of the programme "Sonatina II" (no. 2018/28/C/HS5/000830). The findings and conclusions presented in this paper constitute the results of the comparative research carried out in the Centre for Socio-Legal Studies at the University of Oxford in July-September 2019.
} 


\section{INTRODUCTION}

Consumer protection law has a long tradition in the European Union (Łętowska, 2004). Over the years a number of measures have been taken at the EU level aiming at establishing proper consumer protection (Hodges, Voet, 2018). EU consumers are granted a wide range of rights which are dispersed in a number of the EU consumer directives, implemented to the national legislations. Consequently, in the EU there has been extensive harmonization of Member State's consumer protection law. However, it must be noticed that for consumer rights to be effective there must be effective sanctions in the event the rights are not respected (Eidenmueller, Fries, 2016). In the area of EU consumer law, enforcement is entirely left in the hands of the Member States (Faure, Weber, 2017). The implication is that in the EU mechanisms of consumer law enforcement differ significantly (Mucha, 2019). Bearing this in mind, the aim of this paper is to analyse a range of mechanisms that can be used for the purpose of very specific type of consumer law enforcement, namely collective redress. The author aims to answer the question which of such mechanisms used successfully in different Member States could be implemented in Poland.

The first part of this paper included brief discussion of some terminological remarks regarding consumer collective redress, which was followed by the analysis focused on the legal solutions adopted in Belgium (Mucha, 2019). In the foregoing, the second part, the paper concerns the mechanisms adopted in the Netherlands as well as in England and Wales. Specifically, the discussion presents the opposite approaches to the way in which the represented group is composed in both jurisdictions (so called opt-out and opt-in mechanisms). Special consideration is devoted to the issue of admissibility of collective redress and legal standing to bring collective actions in the Netherland as well as in England and Wales.

\section{THE DUTCH PERSPECTIVE}

Comparing to other EU Member States, in the Netherlands there is a truly unique system of collective redress. It is based on two regulations: (i) the 2005 Dutch Collective Settlement Act (Wet Collectieve Afwikkeling Massaschade, herianfter referred to as the "WCAM") and (ii) the 2020 Act on the Resolution of Mass Claims in Collective Actions (Wet Afwikkeling Massaschade in Collectieve Actie, hereinafter referred to as the "WAMCA"). While the first one has a long tradition of use, the second one is brand new legislative initiative and the first experiences as regards its application are to be observed only in the near future. Interestingly, the mechanisms provided in WCAM and WAMCA may be exploited in a wide range of matters, including (but not limited to) enforcement of consumer rights. It is significant to note that both procedures enable consumers to obtain compensation. In what follows both the mechanisms provided by the Dutch legislator are scrutinised and some examples of the relevant case law are given in order to illustrate how the said mechanisms operate in practice.

\subsection{Collective settlement under the Dutch Collective Settlement Act ("WCAM")}

Introduction of the WCAM in 2005 was considered as a significant step towards a more efficient resolution of mass damage claims in the Dutch legal system (Arons, Van Boon, 2010). What makes this act unique compared to other Member States legislation regarding collective redress is that under the WCAM class actions are admissible only if the collective settlement is reached. The WCAM provides for a specific procedure in cases involving 
declarations that collective settlements of damage claims are binding. The proceedings may be divided into four phases (Krans, 2014).

In the first part of the proceedings which is entirely private and non-court supervised, the parties to the dispute shall reach settlement. On behalf of the claimant it is reached by the Dutch foundation or association with full legal competence representing the interests of the members of the group. The legal standing of such entities is particularly important in the context of commencement of the procedure recognizing the settlement as binding before the court (second phase of the proceedings). On behalf of the defendant the settlement is concluded by one or more parties who have engaged themselves under the settlement to pay compensation for the damage.

In the second phase of the said proceedings, the above mentioned parties to the settlement jointly initiate the procedure recognizing the collective settlement as binding. They submit a joint petition to the Amsterdam Court of Appeal (having exclusive competence to take cognizance in first instance of a request) in which they request the court to make the agreement binding for persons to whom the damage was caused. The Dutch law specifies the admissibility criteria for such request for recognition and the settlement itself. Pursuant to the provision set forth in Article 1018c of the Dutch Code of Civil Procedure the request to the Court shall include (i) the name and place of the petitioners' residence and of the persons known to the petitioners on whose behalf the agreement was concluded, (ii) a description of the event or events to which the agreement relates, (iii) a brief description of the agreement and (iv) a clear description of the request and the grounds on which it was based.

The agreement on collective settlement shall be attached as an appendix to the request. It must include: (i) a description of the event(s) to which the agreement relates, (ii) a description of the group(s) of person on whose behalf the agreement was concluded, specifying the nature and the seriousness of their loss, (iii) possibly most accurate the number of persons belonging to the group(s), (iv) the compensation that will be awarded to these persons, ( $v$ ) the conditions which these persons must meet to qualify for the compensation, (vi) the procedure by which the compensation will be established and can be obtained, (vii) the name and domicile of the persons to whom the written notification regarding opt-out procedure must be submitted (see: Article 7:907 par. 2 of the Dutch Civil Code).

The court shall reject the request if the agreement does not comply with the provisions specified above. It must be noted that the court has influence on the merits of the collective settlement. Among others, it can, reject the request of the parties under the following conditions: the amount of the compensation is nor reasonable, if it is insufficiently certain that the rights of the members of the group resulting from the agreements can be performed, or if the interests of persons on whose behalf the agreement was concluded cannot be adequately safeguarded. Before making a decision, the court may, with the approval of the parties to complete or amend the agreement, or give parties the opportunity to add further contractual provisions to the agreement to change its content.

The collective settlement procedure specified in the WCAM shall be classified as the opt-out procedure. It means that the whole group is composed of the individuals who claim to have been harmed by the same or similar infringement. Unless they opt-out from the group, they can benefit from the judgement and consequently they cannot seek compensation individually. The WCAM provides specific, detailed procedure for the member's participation in the group. In line with opt-out approach a copy of the decision to 
declare the collective settlement agreement binding is sent by post individually to all the persons known to be entitled to the compensation and to the foundations or associations that appeared at the proceedings. Additionally, after the decision has become irrevocable, a notice about the court decision is published in one or more newspapers, designated by the court. Each notice includes a brief description of the agreement. In particular it specifies the method by which the compensation can be obtained and, if the agreement provides so, the period within which the claim for compensation must be made, as well as the consequences of the declaration that the agreement is binding. Importantly, the notice must include the information about the period within which and the procedure by which persons entitled to the compensation can free themselves from the consequences of the declaration that the agreement is binding.

In the third part of the proceedings a person entitled to the compensation who does not wish to be bound by the agreement must notify it in writing, within the period determined by the court (at least 3 months following the announcement of the court decision). The declaration that the agreement is binding has no consequences for such person who opted out within the specified timeframe. Additionally, it has also no consequences for the person entitled to compensation who could not have known of his damage at the time of the announcement but who has notified a person mentioned in the settlement agreement in writing after becoming aware of his damage that he does not want to be bound by the agreement.

In the fourth phase of the proceedings the compensation shall be paid to the all members of the group who have not opted out.

\subsection{Examples of the collective settlements concluded under the WCAM}

Since WCAM in the current shape was introduced over 15 years ago, the mechanism of collective settlement provided by this act has been tested several times so far. Before introduction of WCAM in 2005, the Dutch law had two key limitations. Firstly, it was impossible to claim compensation for injured persons collectively (Hodges, Voet, 2018). Secondly, it lacked the possibility to force the injured persons into settling mass claims with some degree of finality (Arons, Van Boon, 2010). These weaknesses of the Dutch law became particularly visible against the background of the in the pharmaceutical product liability case DES (Tillema, 2016). In order to address the problems which occurred in this case, the WCAM has been introduced.

\section{DES case}

The case concerned several thousand women suffering for the cervical and breast cancer. The injures occurred as a result of application of the DES hormone which was taken by the mothers of the injured women during their pregnancy. The Dutch Supreme Court examined the issue of causation between the physical injuries and the fact of taking the medicines including DES hormone by women and found that the pharmaceutical industry is liable for the injuries. The DES manufacturers wanted to reach the settlement, however under the Dutch law it was only possible to be settled individually. Since the total number of the persons negatively influenced by DES was estimated at the level of 400.000, the statutory legislation was indispensable to make the collective settlement binding (Van der Heijden, 2010). The victims were represented by the DES Centre- organisation which was created in order to protect the interests of the DES daughters. The DES manufactures established a fund that included 35 million of euro and wanted to pay compensation to the 
victims, provided that the settlement is final for all the Dutch victims. In order to manage the settlement, the Dutch Ministry of Justice was looking for a general solution which could be also applied in the similar cases in the future. As a result of the DES case the WCAM was introduced. In line with this new legislation in 2006 the Amsterdam Court of Appeal declared the settlement binding.

\section{Converium case}

Although the WCAM was initially designed to respond to the problems with the management of the product liability case, over the years it was used in the cases regarding financial products and securities (Bosters, 2017). One of the most famous collective settlement which was considered binding by the Amsterdam Court of Appeal was the Converium case. It concerned Swiss reinsurance company Converium and the Zurich Financial Securities (ZFS) which owned the shares in Converium. The shares were listed in the Swiss Stock Exchange and on the New York Stock Exchange (as American depository shares). After the ZFS had sold the shares through the public offer, the value of the shares plummeted since the Converium increased its loss reserves. As a result, a number of class actions was brought by several investors coming from various jurisdictions. In the United States the settlement was reached, however according to the court in the New York it was binding only for the US class members. Therefore, investors stemming from different jurisdictions (including the Netherlands, the UK and the Switzerland) concluded a parallel settlement which was brought to the Amsterdam Court of Appeal. The court ruled that is has an international jurisdiction to approve of the settlement of non-US class members. Such ruling was viewed as surprising since in this case there was no link to the Netherlands. The claims were not brought under the Dutch law, the shares were not traded on the Dutch stock exchange, the alleged wrongdoing took place outside the Netherlands, none of the potentially liable parties and only a limited number of the potential claimants were domiciled in the Netherlands (Knigge, Wijnberg, 2020). In its decision of 2012 the court held the settlement in the amount of 58 million of euro binding to all the class members. Quite interestingly it ruled that the American lawyers involved in the settlement can obtain a contingency fee in the amount of the $20 \%$ of the settlement. In the international legal environment the decision was widely discussed - Amsterdam was called a global hub for international class settlements involving non-US class members (Hodges, Voet, 2018; Clifford Chance 2012).

\section{Ageas (Fortis) case}

Another interesting settlement approved of by the Amsterdam Court of Appeal was the one concluded in the Ageas (Fortis) case in 2018. The value of the case amounted to 1,3 billion euro and so far it is the largest settlement of this kind approved of in Europe. The case concerned the Ageas, the legal successor of Fortis- a Belgian-Dutch bank insurance group which started its international expansion. The dispute arose in relation to the takeover of one of the Dutch banks by the consortium of three banks, including Fortis. In order to finance the transaction Fortis increased the amount of capital and issued new shares to the existing shareholders at the lower price. The dispute referred to the alleged misleading statements of Fortis towards its shareholders. When the shares of Fortis went down the company announced that it is more seriously exposed to the US subprime market and decided to limit the dividend to the shareholders (Declève, 2017). After the fall of the US Lehman Brother bank the Fortis customers started to withdraw their deposits and the share 
price dropped again and there emerged a serious risk that the Fortis would declare bankruptcy. In order to prevent it the Dutch and Belgian governments proposed nationalisation of Fortis. As a result many proceedings against Fortis were initiated by its shareholders in Belgium, the Netherlands and in the US. In 2016 all the parties reached settlement according to which the Ageas was supposed to pay 1,2 billion euro compensation to all of its shareholders who held shares in the specific timeframe. In 2016 the settlement was submitted to the Amsterdam Court of Appeal which declined to approve the settlement. The court found that it should not vary the amount of compensation for active and passive claimants (who filled the legal proceedings before and after the settlement was announced, respectively). It also criticised the amount of the fees paid to the organisation representing the shareholders. As a consequence the parties concluded a revised settlement agreement which, among others, included a 100 million euro increase of the settlement ${ }^{3}$. In 2018 the court approved the revised settlement agreement, stating 5 months term for shareholders to opted out ${ }^{4}$. Until now more than 1 billion euro has been paid as a compensation to the shareholders ${ }^{5}$ who did not opt out and filed the claims for payment.

\subsection{Collective actions under the Dutch Act on the Resolution of Mass Claims in Collective Actions ("WAMCA")}

Before 2020, the Netherlands had a system of collective redress in which the representative entities (Dutch foundations or associations) could have sought only a declaratory or injunctive relief on behalf of the class claimant. Compensation could have been awarded to the group only be means of collective settlement approved by the Amsterdam Court of Appeal under the WCAM. Starting from 1 January 2020, this route was extended by the new legislation - the WAMCA - and now the foundations and associations acting on behalf of class members can also claim damages arising out of the harm suffered. In order to make a claim for damages admissible, the collective action must relate to the event which took place on or after 15 November 2016. The former regime, enabling seeking declaratory or injunctive reliefs only, remains in force in relation to the collective actions arising out of the events which took place before 15 November 2016 and/or to the actions initiated before 1 January 2020.

The WAMCA provides for specific requirements relating to the legal standing of the foundations and associations which may bring the class action. Under Article 305a of the Dutch Civil Code, at the first place they must have a full legal capacity. In order to institute a legal action for the protection of the similar interests of the group members, the foundations or associations must represent these interests by virtue of their articles of association. The said interests must be also sufficiently safeguarded, which is reflected by the obligation of the entity bringing a representative collective action (i) to have a supervisory board, (ii) to provide appropriate and effective mechanisms for the participation or representation in the decision-making of the members of the group, (iii) to

${ }^{3}$ Revised settlement agreement in English is accessible online at. Access on the internet: https://www.forsettlement.com/pdf/Second_Amended_and_Restated_Settlement_Agreement_ E.PDF?v=1.3.3

${ }^{4}$ https://corporatefinancelab.org/2018/07/16/revised-e13-billion-settlement-in-the-fortis-caseapproved-by-dutch-court/ [Access: 20.11.2020].

5 Updated information regarding the settlement and amount of payments are available online [Access: 20.11.2020]. Access on the internet: https://www.forsettlement.com/ 
have sufficient resources to bear the costs of instituting class action, (iv) to have a generally accessible internet page which includes several information ${ }^{6}$; and (v) to have sufficient experience and expertise with regard to instituting and conducting legal claims.

Unlike the WCAM, the WAMCA provides that the Dutch courts will have a jurisdiction over the class action only if the sufficient link with the Netherlands exists. In line with Article 305a para. 3 of the Dutch Civil Code, the class action has a sufficiently close relationship with the Dutch legal order when (i) the majority of the group members have their habitual residence in the Netherlands or (ii) the defendant is domiciled in the Netherlands and additional circumstances indicate sufficient relationship with the Dutch legal order or (iii) the event or events to which the legal claim relates has or have taken place in the Netherlands. Class actions initiated under WAMCA shall be brought to the one of the district courts in the Netherlands. The general rule is that the claim shall be brought to the court in the place of the defendant's domicile.

In order to make the claim admissible the entity representing the class must also contact the defendant before submitting the claim. The Article 305a para. 3c of the Dutch Civil Code stipulates that the period of two weeks after the defendant receives the request for consultation, stating what has been claimed, is in any case sufficient.

Apart from examining the criteria specified in the Article 305a of the Dutch Civil Code, as discussed above, the court also verifies whether the collective action is more efficient and effective that than filing an individual claim (i.a. it verifies whether the factual and legal questions are similar to all the group members, whether the number of the persons affected is sufficient, and - in relation to the claims for damages - whether the members of the class individually or jointly have a sufficiently large financial interests in the claim).

An interesting novum provided by the WAMCA is a Dutch central register for collective actions ${ }^{7}$. Under Article 1018c of the Dutch Code of Civil Procedure the representative entity, submitting the class action is obliged to make a note of this action in a said register within two days of submitting the claim. For the purpose of consolidation of several proceedings, within three months after the entry of the class action to the register, a different foundation or association meeting the criteria specified in the Article 305a of the Dutch Civil Code may also institute a collective action relating to the same event or events, invoking similar factual and legal issues. The class action must be brought to the same court as where the class action previously entered in the register was filed. In such case the judge shall designate the representative entity that is most suitable from among the entities who have brought class action as exclusive representative, taking into account the size of the group, the size of the financial interests represented by the group, other activities that it performs and previous activities or collective actions, brought by such representative entity.

Within 6 weeks following the expiry of the three month deadline for the entry of class action into the public register of class action, the defendant shall submit the statement of

\footnotetext{
${ }^{6}$ The website shall contain information relating to the status of the legal person, its management structure, the most recently adopted supervisory and management annual reports, remuneration of directors and members of supervisory board, the objectives and working methods of the legal person, an overview of the state of affairs in pending proceedings, information on how the members of the group may join the legal person and how they can terminate this affiliation.

${ }^{7}$ See: The Dutch Central Register for Collective Actions [Access: 22.11.2020]. Access on the internet: https://www.rechtspraak.nl/Registers/centraal-register-voor-collectieve-vorderingen\# 6f1c15a9-f3e8-4b9b-ab79-4b3bb766c72f6bc1d2e4-e511-4e04-bf16-8ad720b8f8b319.
} 
defense. The WAMCA provides an opt-out model of the membership in the class action for the members of the group who have a domicile or residence in the Netherlands. It means that the Dutch members of the group will be automatically bound by the judgement of the court unless they opt out within the time frame determined by the court. On the other hand, for the non-Dutch members of the group, the opt-in membership model is stipulated, which means that in order to benefit from the collective action they need to agree to be represented in the collective claim within the time frame, specified by the court. At the request of the party the court may determine that the opt-out model is also applicable for non-Dutch members of the group.

\subsection{The WAMCA in practice}

Although the WAMCA was introduced only a year ago there is already some feedback regardig how effective it is in practice. Thanks to the public register of class actions one may find that since January 202017 class actions have been brought to the Dutch courts ${ }^{8}$. In what follows I discuss some of the most interesting cases.

\section{Volkswagen case}

The first case is worth mentioning here not only from the Dutch, but also from the global perspective. It concerns the international Volkswagen emission scandal, known also as "Dieselgate". In September 2015 German carmaker was found to have misled the authorities and consumers by installing defeat devices in the diesel cars, which enabled cheating the emission tests. Volkswagen group admitted that about 11 million of cars worldwide, including 8 million of cars in Europe were equipped with such defeat devices (Hotten, 2015). The car manufacturer reached settlements with large groups of car owners including those from the U.S., Canada and Australia. Thanks to the U.S. class action system the largest settlement so far was concluded in the U.S. and it amounted to 10 billion USD, with 500.000 owners of polluting diesel cars. Unlike in the U.S., in the EU the legislation regarding collective redress is still fragmented and therefore Volkswagen clearly benefits from the lack of coordinated litigation in Europe. By the way of example, as a result of the settlement concluded in Germany 230.000 consumers will receive 830 million EUR compensation, which constitutes a fraction only of what the VW company paid to American car owners.

Introduction of WAMCA in January 2020 opened a door for class action against Volkswagen group in the Netherlands (Celis, 2020). The case was brought in March 2020 before the Amsterdam District Court by Diesel Emission Justice Foundation (DEJF) ${ }^{9}$. DEJF requested the court to be appointed as an exclusive representative of the Dutch buyers (optout membership) and non-Dutch buyers, residing or based in the EU Member States (optin membership). The Foundation alleges that the Volkswagen Group intentionally and systemically manipulated 8.5 million of European vehicles to pass emission tests. DEJF claims that consumers suffered damages since they bought cars fitted with a defeat device which they would not have bought if they had known about it and its effects, or they had

\footnotetext{
${ }^{8}$ Ibidem.

9 See: Writ of summons is available on the website of the Dutch Central Register for Collective Actions. Access on the internet: https://www.rechtspraak.nl/SiteCollectionDocuments/ dagvaarding-collectieve-vordering-volkswagen-cs.pdf.
} 
done so but under other conditions ${ }^{10}$. According to DEJF “(...) the residual value of the Affected Vehicles fell drastically as the Diesel Scandal became public. In addition, it seems that Affected Vehicles consume more fuel, have higher maintenance costs and offer poorer driving performance than what we have been led to believe. And the Affected Vehicles are in danger of becoming obsolete due to the introduction of environmental zones in inner cities and increasing nitrogen problems in general" 11 . In view of the above, DEJF claims for: (i) annulment, termination and cancelation of purchase agreements concluded between VW dealers and affected parties or lease(s) on the basis which the affected vehicles were made available to the affected buyers; (ii) the provision of the new vehicle that in terms of performance, driving style, appearance and value is similar to the affected vehicle and (iii) damages. Currently, the Foundation represents 10.000 of group members from all across the Europe with over 100.000 cars. The case is still pending and the court has scheduled the first substantive hearing on January 2021.

\section{Daimler AG (Mercedes Benz) and Fiat Chrysler NV cases}

Over a time it became clear that Dieselgate is not limited to just one car manufacturer. Therefore, the DEJF Foundation brought also another class actions before Dutch courts relating to "Dieselgate" emission scandal. On June 2020 it issued a writ of summons before the Amsterdam District Court against Daimler AG, producer of Mercedes Benz vehicles, its Dutch importers and individual dealers for the damages resulting from the use of manipulation software to falsify emission testing ${ }^{12}$. The DEJF requested the court to act as a exclusive representative, representing all the affected Dutch and European car owners. The facts here are very similar to the Volkswagen case and they concern defeat device software, installed in the Mercedes vehicles. German Road Vehicle Authority (Kraftfahrtbundesamt, KBA) in administrative order, requested Daimler to conduct mandatory recall of the Mercedes-Benz cars with diesel engines in Europe (about 670.000 vehicles). The Foundation claims that the car owners suffered severe damages including, among others, " (...) the risk that type approval will be withdrawn, that the vehicles will be taken off the road, use restrictions, decreased resale values, increased maintenance costs." 13 The corresponding case was filed by the DEJF Foundation in August 2020 against another car manufacturer Fiat Chrysler Automobiles N.V. ${ }^{14}$ Both cases are still pending- the dates of the hearings before court have not been yet determined.

${ }^{10}$ Ibidem; see also the description of the case provided by the DEJF in English. Access on the internet: https://ps-image-bucket.s3.amazonaws.com/emissionsjustice/wp-content/uploads/2020/03/ 20200313-Dagvaarding-VW-et-al-EN-Summary2712.pdf para 19.

11 Ibidem.

12 Writ of summons is available on the website of the Dutch Central Register for Collective Actions. [Access: 12.11.2020]. Access on the internet: https://www.rechtspraak.nl/SiteCollection Documents/dagvaarding-collectieve-vordering-Daimler-AG-c.pdf; see also information on the website of the DEJF Foundation [Access: 22.11.2020]. Access on the internet: https://www. emissionsjustice.com/wp-content/uploads/2020/06/Daimler-press-release-EN-2020062350.pdf

13 Ibidem.

14 Writ of summons is available on the website of the Dutch Central Register for Collective Actions [Access: 22.11.2020]. Access on the internet: https://www.rechtspraak.nl/SiteCollection Documents/dagvaarding-collectieve-vordering-\%20fiat-chrysler-automobiles-nv-cs.pdf 


\section{Evolve Media case}

A different group of class actions that can be brought under WAMCA includes cases for an ideological purpose which represent very little financial value. Such cases might be filed with more lenient criteria of admissibility. One of such class actions was brought in February 2020 by the Dutch foundations Stop Online Shaming and EOKM Foundation against Evolve Media (owner of the website vagina.nl)which exploits nude images without permission of the people in the picture. ${ }^{15}$ The foundations claim that when using hidden cameras people did not know that that they have been filmed. The foundations underline that such online shaming cause severe damages such as reputation damages, problems in private sphere, social isolation, loss of work, fears and depression ${ }^{16}$. The aim of this class action is to stop privacy violations, to prevent such content being offered online again and to ensure that the wrongdoers cannot hide behind false names. The proceedings have been brought before the Amsterdam District Court which found that the foundations are admissible to submit the class action. In November 2020 the court issued an interim judgement in which it made a suggestions for the way in which persons who are or have been visible on the website against their will by means of advertisement, they can contact the court. Neither claimants nor defendant have responded to the court suggestions so far. The said case is still pending.

\section{Oracle case}

Another interesting case submitted under WAMCA is the class action against technology group Oracle. It was brought by the Privacy Collective Foundation in August $2020^{17}$. According to the Foundation, Oracle and Salesform.com violated the General Data Protection Regulation (GDPR) several times by using cookies to collect data from Dutch people. The information was distributed amongst online advertisers without the user's consent ${ }^{18}$. The Foundation claims that such misuse of personal data violates the right to private and family life and their right to the protection of personal data, arising out of EU Charter of Fundamental Rights, GDPR and the Dutch Telecommunication Act. The alleged breach of the law consisted in: (i) the application of automated decision-making, (ii) processing personal data without legal basis, (iii) non-transparent processing, (iv) infringement of the principle of data minimalization and (v) the unlawful transmission of personal data to the US ${ }^{19}$. Privacy Collective seeks for monetary damages in amount of 500 euros per victim per company (Oracle and Salesform) and assumes that the number of affected people is 10 million, which makes the total value of the claim amounting to 10 billion euro damages. Defendants call the lawsuit misleading, based on misrepresentation and groundless. The said case is still pending.

${ }^{15}$ See: Writ of summons is available on the website of the Dutch Central Register for Collective Actions [Access: 22.11.2020].Access on the internet: https://www.rechtspraak.nl/SiteCollection Documents/dagvaarding-collectieve-vordering-vagina.nl.pdf

16 https://www.stoponlineshaming.org/

${ }^{17}$ See: Summons available on the website of the Dutch Central Register for Collective Actions. Access on the internet: https://www.rechtspraak.nl/SiteCollectionDocuments/RBAMSdagvaarding-collectieve-vordering-Oracle-Nederland-BV-SFDC-Netherlands-BV-OracleCorporation-Oracle-America-Inc-Salesforce.pdf

$18 \mathrm{https}: / /$ theprivacycollective.eu/en/

19 Point 4.6.1-4.6.5 of the Summons... 


\section{THE ENGLISH PERSPECTIVE}

Collective redress instruments are also well-known in England and Wales. Under the English law there exist two structures enabling collective redress, namely the representative actions and group litigation order (hereinafter referred to as the "GLO"). First mechanism enables individuals to bring an action on behalf of other parties without their consent, where the represented parties share the same interest ${ }^{20}$. The same interests is defined by the courts narrowly and therefore representative actions are allowed only for claimants which near identical fact patterns and loss to be grouped together ${ }^{21}$. Since in practice use of this mechanisms is of little relevance, especially in terms of consumer claims (Hodges, Voet, 2018), it will not be examined in what follows. On the other hand, the second means, which is the group litigation order, although highly criticized in the doctrine, is still the principal procedure of consumer collective redress in England and Wales and therefore it is worth scrutinising.

\subsection{Group Litigation Order (“GLO”)}

Group litigation order is a mechanism which provides for the case management of individual claims which gave rise to "common or related issues of fact or law", known as GLO issues. The GLO is ordered by a court at the request of the parties or of its own initiative. Interestingly, application for the GLO may be made either by a claimant or a defendant at any time before or after any relevant claims have been issued. In support for the application for the GLO the applicant shall provide a summary of the nature of the litigation, the number and nature of claims already issued, the number of parties likely to be involved, the GLO issues that are likely to arise in the litigation and information whether there are any matters that distinguish smaller groups of claims within the wider group.

The English Civil Procedure Rules ("CRP") provides for some obligatory and facultative elements of GLO. Firstly, pursuant to the provisions of Article 19.13 of the CRP it must: (i) contain directions about the establishment of a register on which the claims managed under the GLO will be entered (so called "the group register"), (ii) specify the GLO issues which will identify the claims to be managed as a group under the GLO and (iii) determine the court which will manage the claims on the group register (so called "managing court"). Once GLO is ordered the managing court may give directions regarding varying the GLO issues, providing for one or more claims on the group register to proceed as test claims, appointing the solicitor to be a lead solicitor for the claimants or defendants, specifying the details to be included in a statement of case in order to show that criteria for entry of the claim to the register have been met, specifying a date after which no claim may be added to the register unless the court gives permission to do so and for entry of any particular claim which meets one or more of the GLO issues on the group register.

The proceedings follow the opt-in regime, which means that potential members of the group must actively opt-in in order to benefit from the judgement. Once the GLO is ordered a group register is created which involves the names of the claimants who are the parties to the GLO. The register is open for a specific timeframe during which potential claimants may join the procedure. Maintaining and updating the group register is a task of the lead solicitor, as approved by the court. A judgement in the GLO is binding on the parties to all other claims that are signed-in the group register at the time the judgement is given unless

\footnotetext{
20 See: Civil Procedure Rules 1998, Part 19.6.

${ }^{21}$ https://www.lexology.com/library/detail.aspx?g=1c9a6bc7-6189-462a-a89c-56c5b146dc96
} 
the court orders otherwise. The court may give directions as to the extent to which that judgement is binding on the parties to any claim which is subsequently entered on the group register. Any party who is adversely affected by the judgment which is binding on him may seek permission to appeal the GLO.

\subsection{GLO in practice}

Over the past 20 years there were 109 group litigation orders issued by the courts in England and Wales. One in five of them relates to consumer protection ${ }^{22}$. One may wonder whether this amount is relevant for consumer law enforcement. It is very difficult to answer this question unequivocally since the outcomes of the GLO's are not known (Hodges, Voet, 2018). In order to examine how this mechanisms operates in practice, the section to come will discuss some of the most recent cases in which the GLO was or is planned to be issued are scrutinized.

\section{Volkswagen case}

The group action against Volkswagen discussed above in relation to the consumer collective redress in the Netherlands was also a subject of group proceedings in England and Wales. The investigation shows that defeat devices were installed by the car manufacturer in the 1.2 million cars owned in the UK. So far the case is considered the largest consumer group action to come before the English courts.

In March 2018 the GLO was issued by the High Court in London. The legal action has been brought on behalf of British car owners over allegations that the Volkswagen had software fitted to their vehicles which cheated the EU emissions tests. Under the GLO two law firms were appointed as a leading solicitors. The advertisements about the GLO were published in the national newspapers in May $2018^{23}$. The potential claimants who wished to be added to the group register of claims were granted the time till October 2018 to contact solicitors in order to join the group action. The action was brought under the Consumer Protection from Unfair Trading Regulation 2008. One of the leading solicitors - Leigh Day law firm claimed a refund of at least $50 \%$ of the value of the car or finance repayments. In order to join the group the vehicle must have been bought for personal, not business use from an approved dealer of VW group directly and paid for on or after October 2014. In total, in the group register the claims were registered by almost 100.000 consumers from the UK.

In April 2020 the High Court in London ruled in favour of consumers. The court found that the decision of the German Road Vehicle Authority Kraftfahrtbundesamt, KBA), stating that the affected vehicles contained a defeat device is binding for the English courts. The court also decided that the fact that the engines operated in different modes during the emissions tests means that it contained a defeat device under the EU emissions regulations ${ }^{24}$. Volkswagen appealed from this ruling but its appeal was rejected by the court. According

${ }^{22}$ List of all group litigation orders issued in England and Wales since 1999 is published online [Access: 11.11.2020]. Access on the internet: https://www.gov.uk/guidance/group-litigationorders\#history

${ }^{23}$ The advertisement of the group action published in the newspaper [Access 11.11.2020]. Access on the internet: https://www.leighday.co.uk/getmedia/a9ff8ca0-9c1a-42c5-b97e-409ef9e7f0e4/TheVW-NOx-Emissions-Group-Litigation-ad2.aspx

${ }^{24}$ Judgment of the Mr. Justice Waksman as of 6.4.2020. [Access: 20.11.2020]. Access on the internet: https://www.judiciary.uk/wp-content/uploads/2020/04/VWJudgment-002.pdf. 
to the leading plaintiff, in spite of such decision, VW group continues to deny the claims in the UK and it does not want to enter into settlement negotiations. According to VW, it does not owe the compensation for consumers since they have not suffered any loss. The said case is pending.

\section{Daimler AG (Mercedes Benz) case}

Similarly to the situation which occurred in the Netherlands the "Dieselgate" emission scandal which referred to the Volkswagen cars, was expanded to other car manufacturers in the UK. Another group action has been brought against Daimler AG, the producer of Mercedes Benz vehicles. In June 2020 the law firm PGMGB announced that launched the group action before the High Court of Justice in Liverpool on behalf of the Mercedes customers from England and Wales ${ }^{25}$. The claim is based on the German authorities (KBA) findings that Mercedes Benz vehicles were equipped with illegal defeat device. The law firm believes that Daimler deliberately misled its customers as to the real level of emissions in their vehicles. The damage suffered by consumers is justified in the similar way as it was done in the Netherlands: as a result of the KBA's administrative order Daimler updated the software in the affected vehicles in order to remove defeat devices, which may have directly reduced vehicle performance, forced the consumers to pay increased maintenance bills and higher fuel costs. Additionally, the claim is based upon the statement that the customers and their children may suffer pulmonary problems from breathing-in high volumes of toxicants in polluted air $^{26}$. The PGMGB law firm informs the potential claimants that the compensation may amount to entire purchase price of the vehicle. Although there is not upfront fee to join the group action, the PGMGB law firm deducts up to 50\% success fee from the awarded compensation.

Interestingly, there is also another UK law firm - Leigh Day which launched the group proceedings against the Daimler in the same case on behalf of 288 consumers and ${ }^{27}$. Unlike the PGMGB, Leigh Day states that the claims could be worth up to $75 \%$ of the purchase price of the vehicle and declares that in case of success the law firm's fee will amount to $31 \%$ of the awarded compensation ${ }^{28}$. Currently, there is no information whether any of the law firms requested the GLO. The said case is pending.

\section{CONCLUSIONS}

The analysis conducted so far shows that the Dutch and the English legal systems of collective redress are very different. While the Dutch approach is based upon the opt-out model, in England and Wales the legislator chose the opt-in model. While consumers in the Netherlands may be represented by the Dutch foundations and associations only, in England

${ }^{25}$ Information regarding the case are available online at the website of the law firm PGMGB law firm, dedicated to the group action. \{access: 11.11.2020]. Access on the internet: https://mercedesclaimlawyers.com/

${ }^{26}$ Ibidem.

${ }^{27}$ Information regarding the commencement of the group action against Mercedes by the Leigh Day law firm [Access: 11.11.2020]. Access on the internet: https://www.leighday.co.uk/News/Pressreleases-2020/December-2020/Leigh-Day-launches-claim-against-Mercedes-Benz.

${ }^{28}$ Information from the website of the law firm Leigh Day dedicated to group action against Mercedes [Access: 11.11.2020]. Access on the internet: https://www.leighday.co.uk/Product-safety-andconsumer-law/Consumer-law/Car-emissions-claims/Mercedes-Benz-emissions-claim 
and Wales consumers are represented by the law firms, acting as the group representatives. Thanks to the existence of the group register, the Dutch system seems to be very transparent and accessible for the consumers, especially taking into the account that under the WAMCA all the writs of summons are published online. On the other hand, in England and Wales, at the GLO's website there is only fragmented information about the GLO issued by the English courts.

It needs to be noted that the English system, although based on the opt-in approach, seems to be similar to the American class action system in the way that various law firms are competing in order to represent the group of consumers, requesting at the same time quite high success fees (including even $50 \%$ of the compensation awarded). However, it is noted that in practice it is difficult to fulfill the requirements set for the GLO, and therefore the total number of GLOs, amounting to 5 per year is not significant. From this perspective, GLO procedure might be perceived as not effective way of seeking consumer redress. On the other hand, it shall also be noted that once the GLO is issued the case involve mostly large groups of members and therefore, in case of judgements issued in favor of consumers the GLO may affect the situation of a wide range of harmed persons. Due to the fact that the outcomes of the GLO's proceedings are not known it is impossible to assess whether the consumers can really benefit from the judgements.

Although the collective redress systems in the Netherlands, England and Wales are not free from imperfections some solutions provided in the Dutch and the English law are definitely worth being adopted in Poland. First of all, it would be very beneficial to draw on Dutch experience and amend the Polish group register in a way that it will enable the potential consumers to get acquainted with the statement of the claim. Although the register of group proceedings exists under the Polish law $^{29}$ it includes only some basic information about the proceedings itself, which is not sufficient to decide whether to join the group. Moreover, for practical reasons it would be very useful to adopt in Poland the possibility of collective settlement without the necessity of commencing litigation. Currently, the Polish law on the group proceedings allows for group settlement only after a group proceeding was initiated, in case when at least half of the group members give their consent ${ }^{30}$. Following the English experience an interesting option to be considered in Poland is also a possibility of requesting group proceeding by the defendant at any time before or after any relevant claims have been issued. One shall note that for reasons of procedural economy not only claimants but also defendant might be interested in participation in group proceedings instead of many individual litigations.

\section{REFERENCES}

Arons, T., Van Boon, W. H. (2010). Beyond tulips and cheese: Exporting mass securities claim settlements from the Netherlands. "European Business Law Review", Vol. 21, Issue 6.

Bosters, T. (2017). Collective redress and private international law in the EU. Springer.

Celis, M. (2020). The Volkswagen (VW) emissions scandal - the saga continues: now it's the turn of the Netherlands, France and Belgium. Access on the internet: https://

\footnotetext{
${ }^{29}$ Polish register of group proceedings is available online [Access: 12.11.2020]. Access on the internet: https://www.gov.pl/web/sprawiedliwosc/wykaz-postepowan-grupowych

30 Art. 19 of the Polish Act of 17 December 2009 on Pursuing Claims in Group Proceedings, Journal of Laws 2010 No. 7 item 44.
} 
conflictoflaws.net/2020/the-volkswagen-vw-emissions-scandal-the-saga-continues-nowits-the-turn-of-the-netherlands-france-and-belgium/

Clifford Chance (2012). The Converium decision: promoting the Netherlands as a centre for class settlements. Access on the internet: https://www.cliffordchance.com/content/dam/ cliffordchance/briefings/2012/02/the-converium-decision-promoting-the-netherlands-as-acentre-for-class-settlements.pdf

Declève, Q. (2017). Fortis's settlement: a comparative case study of securities class action mechanisms in Europe and the United States. "Business Law International” No. 1, Vol. 18.

Eidenmueller, H., Fries, M. (2016). Against false settlement: designing efficient consumer rights enforcement systems in Europe [In:] Micklitz, H., Wechsler, A., The transformation of enforcement. European Economic Law in a Global Perspective, Hart Publishing.

Łętowska E. (2004)., Europejskie prawo umów konsumenckich. Warszawa: C.H. Beck.

Faure, M., Weber, F. (2017). The diversity of the EU approach to law enforcement - towards a coherent model inspired by a law and economics approach. "German Law Review", Vol. 18., No. 4.

Hodges, C., Voet, S. (2018). Delivering collective redress. New Technologies. Hart Publishing.

Hotten, R. (2015), Volkswagen: the scandal explained, BBC. Access on the internet: https://www.bbc.com/news/business-34324772.

Knigge, A., Wijnberg, I. (2020), Class/collective actions in the Netherlands: overview. Access on the internet:, https://uk.practicallaw.thomsonreuters.com/Cosi/SignOn?redirectId= rt_04504288-eca1-4439-b768-809181af0302.

Krans, B. (2014). The Dutch act on collective settlement of mass damages, "Pacific McGeorge Global Business \& Development Law Journal”, Vol. 27, Issue 2.

Mucha, J. (2019). Consumer protection in practice- transnational comparative account of collective redress mechanisms- part one: the Belgian approach. "Humanities and Social Sciences", Vol. XXIV, Issue 26 (4).

Tillema, I. (2016). Entrepreneurial motives in Dutch collective redress: Adding fuel to a 'compensation culture'? [In:] Van Boon, W.H., Litigation, costs, funding and behavior: Implications for the law, Springer.

Van der Heijden, M. J. (2010). Class actions. "Electronic Journal of Comparative Law", Vol. 14 (3).

Russel R. (2011). Amsterdam, the place to settle. Access on the internet: https://www. russell.nl/Uploaded_files/Zelf/Publicaties/AmsterdamthePlacetoSettle1318256115.pdf

DOI: $10.7862 /$ rz.2021.hss.06

The text was submitted to the editorial office: February 2020.

The text was accepted for publication: March 2021. 
